\title{
Laboratory Critical Experiment Simulating Long-Term Exposure to External Environment: A Hollow Brick Block with Mineral-Wool-Fiber Cavity Filler
}

\author{
ZbyšekPavlík, Jan Fořt, Milena Pavlíková, Robert Černý \\ Department of Materials Engineering and Chemistry, Faculty of Civil Engineering, Czech Technical University in Prague, \\ Prague 166 29, Czech Republic
}

\begin{abstract}
The long-term exposure of a contemporary hollow brick block with the cavities filled by hydrophobic mineral wool to the external environment is studied in a laboratory critical experiment. The studied brick block is exposed to difference climatic conditions. On the exterior side winter conditions corresponding to the reference climatic year for Prague, Czech Republic are applied, while on the interior side the conditions for residential houses are simulated. Based on the temperature and relative humidity profiles monitored across the studied brick sample having the real thickness of a single-layer building envelope, it can be concluded that the hygrothermal performance of the block is satisfactory.
\end{abstract}

Keywords-hollow brick, hydrophobic mineral wool, cavity filler, laboratory critical experiment, long-term exposure

\section{INTRODUCTION}

Energy consumption for heating of buildings and their cooling in hot year periods represents a serious global problem that becomes presently more significant not only in the developed countries but also in the developing countries with increasing building industry. Primary energy use in buildings accounts for approximately $40 \%$ of the total European Union (EU) energy consumption, $63 \%$ of which is attributed to residential buildings [1]. In addition, the building sector constitutes a major pollution source; $\mathrm{CO}_{2}$ emissions from residential buildings are the fourth largest source of green-house gases emissions in the EU, accounting for $10 \%$ of the total greenhouse gas emissions.

In EU, there is paid high attention to the energy demands on buildings operation and to the improvement of buildings energy performance. According to the EU parliament directive 2010/31/EU, from 2018 the new public buildings must be built with almost zero energy consumption. Moreover, from 2020 this demand on very low energy consumption will be extended also on residential buildings. Presently, design and development of low energy buildings having annual energy consumption for heating $<50 \mathrm{kWh} / \mathrm{m}^{2}$, and of passive houses of annual heating energy consumption $<15 \mathrm{kWh} / \mathrm{m}^{2}$, is very popular in EU countries. Low energy and passive houses are known to outperform conventional buildings in terms of living conditions and energy efficiency due to their heat recovery, good thermal insulation, and the overall optimization of the house. Among the key features of passive and low energy buildings design as building location and orientation on the site, window design, building layout, shading and ventilation, insulation and thermal mass (heat storage capacity) of building envelopes represent substantial parameters in sustainable building design. The energy efficiency and the living conditions are strongly interconnected through appropriately solved construction details, system solutions like heat recovery, as well as the choice of building materials [2].

In order to meet the above given requirements on low energy consumption for buildings operation and to keep optimal conditions of an interior climate, new sophisticated thermal insulation materials and systems are under development and testing [3].

Hollow bricks are used extensively in the construction of single layer building envelopes because of their useful thermal insulation properties, attributed mostly to the presence of air holes. Concerning the mode of heat transport in hollow bricks, it is generally accepted that overall heat transfer trough the cavity is due to the convective, conductive and radiative transfers. Filling the cavities by thermal insulation materials reduces the heat transfer by radiation and contributes to the higher thermal resistance of brick block compared to the materials with air cavities only. On this account, a new type of hollow brick with cavities filled by hydrophobic mineral wool fibers is investigated in the presented paper.

\section{EXPERIMENTAL}

\section{A. Hollow brick}

Hollow brick block produced by company Heluz Brick Industry, Czech Republic, was the analysed material. The internal cavities of the brick were filled (within the brick manufacturing in brick factory) by hydrophobic mineral wool (see Fig. 1).

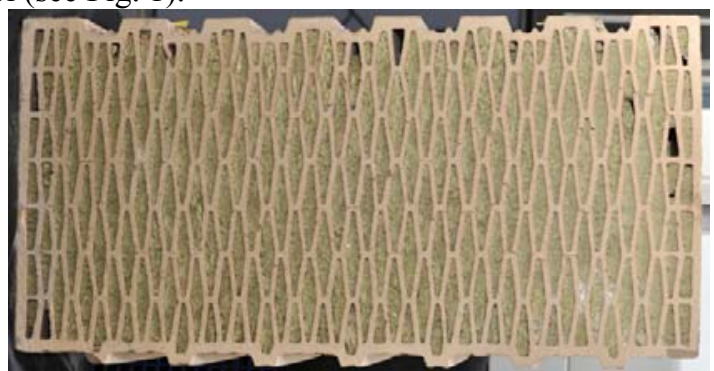

Fig.1: Hollow brick with cavities filled by mineral wool 
The brick was originally designed for application in thermal insulation masonry having a width of $500 \mathrm{~mm}$ that should find use in low energy and passive houses.

The basic physical properties of the brick body are given in Table 1. Here, the bulk density was accessed from the measurement of sample size by digital length meter and its dry mass. Matrix density was determined on helium pycnometry principle. Total open porosity was calculated from the bulk density and matrix density values. Thermal conductivity was measured using steady-state semi-scale experiment for the whole brick block according to the principles given in [4].

TABLE 1: PROPERTIES OF THE STUDIED MATERIAL (BRICK BODY, BRICK BLOCK)

\begin{tabular}{cccc}
\hline $\begin{array}{c}\text { Bulk } \\
\text { density } \\
\left(\mathrm{kg} / \mathrm{m}^{3}\right)\end{array}$ & $\begin{array}{c}\text { Matrix } \\
\text { density } \\
\left(\mathrm{kg} / \mathrm{m}^{3}\right)\end{array}$ & $\begin{array}{c}\text { Total open } \\
\text { porosity } \\
(\%)\end{array}$ & $\begin{array}{c}\text { Thermal conductivity } \\
- \text { brick block }(\mathrm{W} / \mathrm{mK})\end{array}$ \\
\hline 1389 & 2830 & 51.0 & 0.075 \\
\hline
\end{tabular}

\section{B. Semi-scale experiment}

For the realization of the semi-scale experiment, the climatic chamber system described was used, which enabled simulation of the difference climate conditions in the studied brick block sample of real dimensions. The testing device consisted of two commercial climatic chambers for simulation of relative humidity and temperature and a specially developed connecting tunnel for placing the studied samples (Fig. 2).

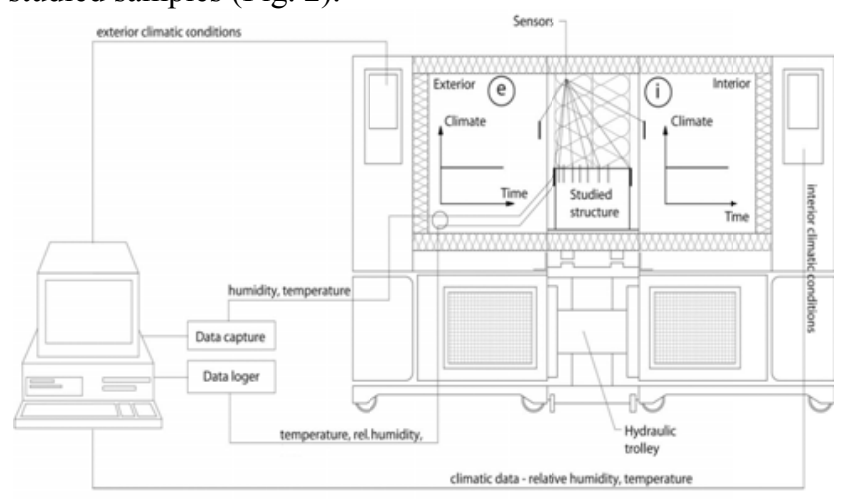

Fig.2: Scheme of the measuring system

The tunnel was vapour proof and thermally insulated from the environment. The investigated brick block was placed into the connecting tunnel, and then provided with the sensors and with the additional thermal insulation consisting of polystyrene boards and polyurethane foam (Fig. 3). Finally, the climatic chamber system was closed, and required temperature and relative humidity values were set. In this way, 1-D heat and water vapour transport transfer across the brick block was simulated.

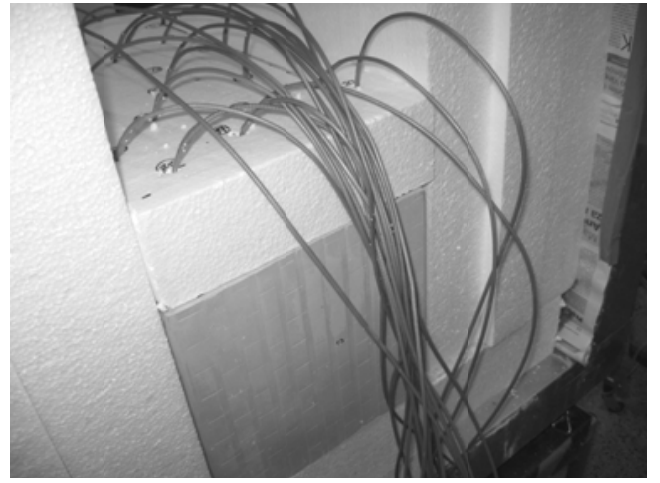

Fig.3: Thermal insulation of the brick block in the measuring system, sensors placing

In the tested sample, continuous monitoring of temperature and relative humidity fields was performed. For monitoring relative humidity and temperature, commercially produced combined mini-sensors by Ahlborn, Germany, were employed. The accuracy was as follows: the capacitive relative humidity sensors were applicable in the $5-98 \%$ relative humidity range with $\mathrm{a} \pm 2 \%$ accuracy, the resistance thermometers had an accuracy of $\pm 0.4^{\circ} \mathrm{C}$ in the temperature range from $-20^{\circ} \mathrm{C}$ to $0^{\circ} \mathrm{C}$, and $\pm 0.1^{\circ} \mathrm{C}$ in the temperature range from $0^{\circ} \mathrm{C}$ to $70^{\circ} \mathrm{C}$. In both climatic chambers were additional control sensors for temperature and relative humidity monitoring.

During the performed experiment, constant temperature $(21 \pm 0.5){ }^{\circ} \mathrm{C}$ and constant relative humidity $(50 \pm 2) \%$ corresponding to the residential houses were maintained in the interior climatic chamber. On the exterior side, climatic conditions of the reference weather year for Prague (Czech Republic) were simulated. The climatic loading started with data corresponding to November 1 and the experiment was stopped with the conditions for March 31.

\section{RESULTS AND DISCUSSION}

The climatic conditions measured in the interior climatic chamber are given in Fig. 4. The monitored temperature and relative humidity were during the whole time of experiment almost constant, taking into account the parameters of used climatic chambers.

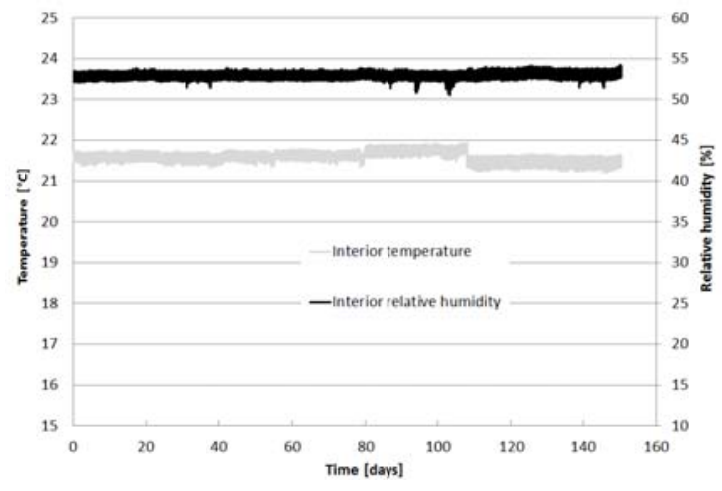

Fig. 4: Interior climatic conditions 
The climatic conditions measured in the exterior chamber are presented in Fig. 5.

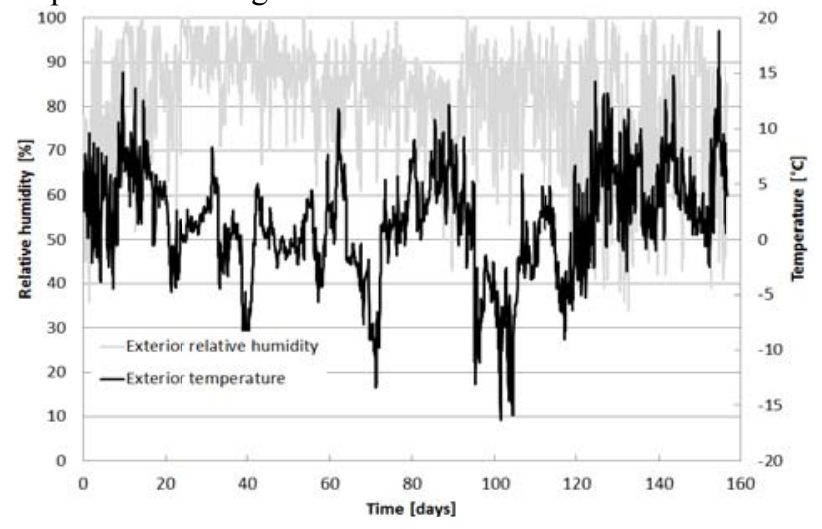

Fig.5: Exterior climatic conditions

At the time interval from November 1 to March 31 that was simulated within the described experiment, high values of relative humidity could be observed, what is common in the autumn and winter periods of the year. The maximum exterior temperature was $18.8^{\circ} \mathrm{C}$, the minimum temperature reached $-16.3^{\circ} \mathrm{C}$.

Temperature and relative humidity profiles measured in the researched brick block during its climatic loading are given in Figs. 6, 7. The data corresponds to the 5th day of the particular simulated month.

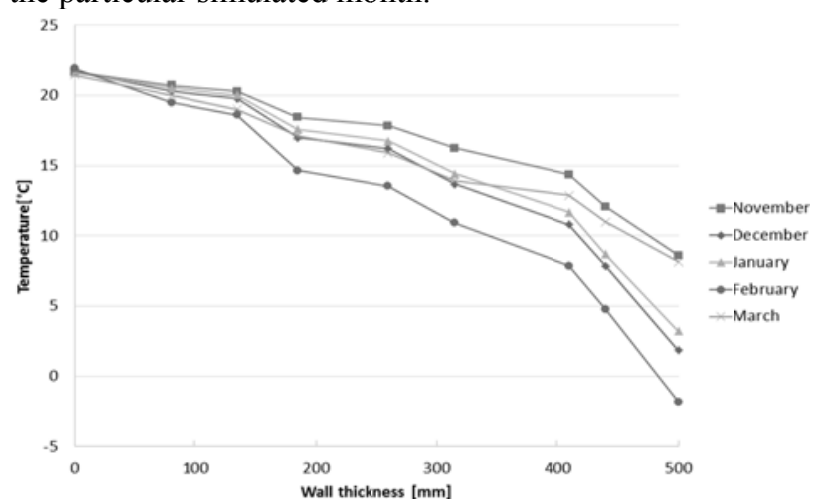

Fig. 6: Temperature profiles measured along the sample thickness

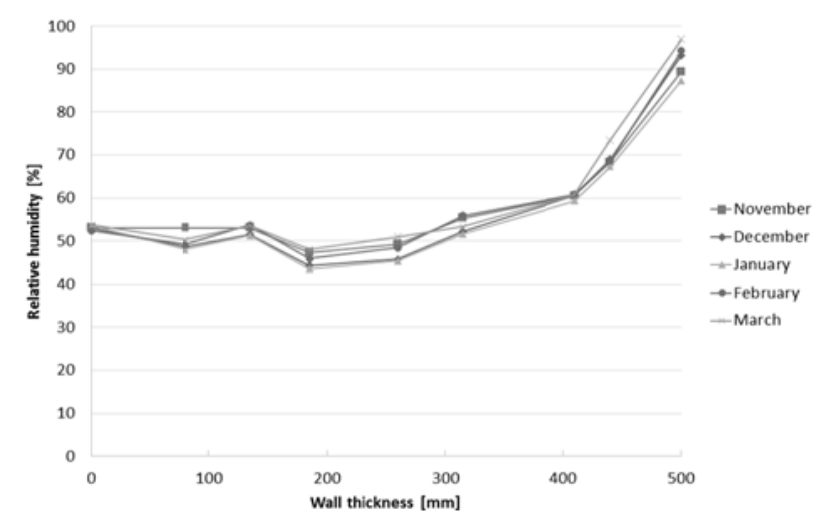

Fig. 7: Relative humidity profiles measured along the sample thickness
Thermal insulation function of the brick can be considered good in general. At $150 \mathrm{~mm}$ distance from the interior surface, there were measured temperatures in the brick about $20^{\circ} \mathrm{C}$ (Fig. 6), what is very good for the conditioning of the interior climate. The lowest temperatures were measured in February. However, the low temperature exposure was compensated by the low heat transport properties of the tested material.

Looking at the relative humidity data (Fig. 7) one can see significant effect of the exterior high relative humidity in the simulated winter period on the brick block performance. Here, up to $100 \mathrm{~mm}$ from the exterior surface the brick block relative humidity reflected the fluctuation of exterior relative humidity. Nevertheless, in the remaining part of the brick block the relative humidity values varied around $50 \%$ what is for the interior conditioning a very good result.

\section{CONCLUSIONS}

The assessment of the hygrothermal performance of a newly developed hollow brick block with the cavities filled by hydrophobic mineral wool in the conditions of a critical laboratory experiment was done. The obtained data showed the effectiveness of the applied cavity filler from the point of view of thermal resistance of the single-layer brick building envelope. The hygric performance of the block was quite satisfactory as well.

\section{ACKNOWLEDGEMENTS}

This work has been supported by the Czech Science Foundation, under project No P105/12/G059.

\section{REFERENCES}

[1] Kolaitis, D.I.,Malliotakis, E., Kontogeorgos, D.A., Mandilaris, I., Katsourinis, D.I., Founti, M.A., Comparative assessment of internal and external thermal insulation systems for energy efficient retrofitting of residential buildings, Energy and Buildings, 64, pp. 123-131, 2013.

[2] Kossecka, E. \&Kosnz, J., Influence of insulation configuration on heating andcooling loads in a continuously used building, Energy and Buildings, 34, pp. 321-331, 2002.

[3] Pavlík, Z., Trník, A., Keppert, M., Pavlíková, M., Žumár, J. \&Černý, R., Experimental Investigation of the Properties of Lime-Based PlasterContaining PCM for Enhancing the Heat-Storage Capacity of Building Envelopes, International Journal of Thermophysics, 29(10), pp. 19411946, 2014.

[4] Pavlík, Z., Fiala, L., Jerman, M., Vejmelková, E., Pavlíková, M. \&Černý, R., Theoretical and Experimental Analysis of MoistureDependent Thermal Conductivity of Lightweight Ceramic Bricks, International Journal of Thermophysics, 35(12), pp. 1912-1921, 2014. 